\title{
The Belarusian Case of Transition: Whither Financial Repression? ${ }^{1}$
}

\author{
Dr. (elect.) Julia Korosteleva and Dr. Colin Lawson ${ }^{2}$ \\ Department of Economics \& International Development, \\ University of Bath
}

\begin{abstract}
The present paper examines the financial development of Belarus over the past decade with a particular focus on 1996-2002, when the financial sector was restrained through pervasive government controls in the form of interest rate ceilings, directed credit and preferential loans schemes, high reserve requirements, multiple exchange rates and capital controls. Belarus is of particular interest, as, despite no economic restructuring, the growth has averaged seven per cent per annum since 1997. While explanations of this 'miracle' abound, no empirical work has been done on the role of the financial system, particularly on the effects of pervasive government intervention. It has been argued that monetary stimulation of investment activity through interest rate ceilings and directed credit and preferential loans revived growth. This paper investigates whether financial policy led to financial deepening and increased the share of savings to be allocated to investment.
\end{abstract}

JEL classification: C12, C22, E42, E44, G21, G28, O16.

Keywords: financial repression, financial sector, financial depth, government intervention, economic growth.

\footnotetext{
${ }^{1}$ The earlier draft of this article was presented at the VII World Congress of ICCEES held in Berlin, Germany, 25-30 July 2005.

${ }^{2}$ The authors acknowledge the comments and help of Dr. Andrew Andrews and Dr. Susan Johnson in the preparation of this article.
} 


\section{Introduction}

It is widely argued that liberalisation of the financial sector by abolishing interest rate ceilings, refraining from directed credit programmes and removing capital controls will lead to financial deepening, and as a consequence to economic growth. In the late 1970-80s many developing countries embarked on economic liberalisation, including financial sectors. Later, the International Monetary Fund and World Bank advised transition economies to adopt financial liberalisation to ensure a successful transition to a market economy.

Financial Liberalisation Theory has ignited much controversy. In most of the less-developed countries and transition economies financial crises occurred around the start date of implementation of a Financial Liberalisation (FL) policy. This supports the argument of FL's detrimental effects on economic development and argues in favour of the gradual withdrawal of the role of the state from economic activity until the necessary institutions are established and the development process is on its right track - free from the influence of the rent-seeking groups or political lobbies.

The presence of information asymmetries and problems of uncertainty in transition economies can lead to markets' inefficiency, making them prone to failures. Particularly, these concern financial markets that are, according to Stiglitz (1994), clearly distinct from other markets. The presence of information imperfections often triggers the problems of adverse selection and moral hazard that together inhibit their functioning. Stiglitz (1994, pp.39-42) also contends that government intervention and financial repression can generally improve the efficiency of capital allocation through lowering the cost of capital and providing directed credits to enterprises with high technological potential. Many economists disagree. In particular, Fry (1997, p.761) noted that 'market failure does not necessarily imply government success'. He also argued that lower interest rates will not necessarily lead to greater capital efficiency because firms with lower-return projects are likely to get loans.

The question of government intervention versus free markets raises more interest when it is put in the context of transition experience. The success of Hungary, 
the Czech Republic, Poland and the Baltic countries tempts many to recognise the triumph of the orthodox approach. At the same time some less successful episodes of FL in the majority of Former Soviet Union raise question about whether FL policy could pave the way to financial deepening and economic prosperity.

The present paper analyses the effects of financial restraints on financial development in Belarus, and their impact on growth.

The paper proceeds as follows. Section 1 introduces the theoretical framework which is drawn from two main strands of the literature - the McKinnon and Shaw paradigm (1973), and the literature which addresses market imperfections. Section 2 provides a detailed analysis of Belarusian financial policy-making 1990-2002 to see if the policies and controls constitute financial repression according to its classical definition. Section 3 evaluates the impact of financial restraints on financial deepening with further inferences drawn for the Belarusian economic growth pattern of the late 1990s. The main findings on the Belarusian experience of financial repression and how they fit into the debates on the role of government intervention into the economy are discussed in the conclusion.

\section{Financial repression: theory and evidence}

The term Financial repression (FR) was first introduced by McKinnon (1973) and Shaw (1973). Following them, FR can be defined as a set of government policies and controls on the financial sector, primarily interest rate ceilings, requirements for banks to hold government bonds or finance government budget deficits, directed credit schemes to support 'selective' industries, high reserve requirements, and administratively regulated foreign exchange rates, all of which restrain financial intermediaries' activities. The policies of FR are also accompanied by the introduction of capital control restrictions to prevent access to foreign markets by both savers and borrowers. The distortions from financial repression, particularly interest rate ceilings, discourage saving, and in reducing the average productivity of capital through the replacement of high-yielding investments with low-return ones, reduces growth. Thus, raising interest rates to equilibrium levels and freeing foreign exchange rates, reducing reserve requirements, eliminating priority lending, or in general, introducing Financial Liberalization (FL), were regarded as the tenets of a growth-enhancing policy. The latter gave rise to the conventional transition approach, 
advocated by the IMF and the World Bank, for economies whose financial systems inherited from a planned economy were regarded as inefficient and restrictive.

A second strand of literature addresses market imperfections in transition economies. Information asymmetries and uncertainty rendered emerging financial markets in many of them inefficient and unstable. Thus government intervention was proposed to address market failures. Furthermore, 'optimal' financial repression was advocated to raise growth through improving the efficiency of capital allocation.

Financial repression has been widely studied in developing counties, which sometimes pursue strategies resulting in 'shallow finance'. ${ }^{3}$ Most researchers conclude that FR damages financial development and consequently growth. However, in their studies of financial repression in India and South Korea, Dematriades and Luintel $(1997,2001)$ conclude that different degrees of repression as well as crosscountry institutional differences can lead to contrasting results - on the one hand, resulting in financial disintermediation in the case of India, and, on the other, positively affecting economic growth by addressing market failures in the case of South Korea.

High rates of economic growth in Belarus coincided with the period of financial repression policy pursued by the authorities since the late 1990s. Is Belarus another successful FR case like South Korea? Or is it a negative case like India? These questions will be addressed in the next sections of the paper.

\section{An Overview of financial development in Belarus in 1990-2002}

Before analysing the developments in Belarus' financial sector, it will be useful to distinguish the following three periods in the Belarusian economic policy-making:

\section{-1991-1993 - 'Preserving the status quo' policy as a substitute for reforming the}

national economy. Unlike CEE and the Baltic countries, Belarus was different in making its radical choice after the collapse of a planned economy. Gaining independence in 1991 was not the result of a Belarusian societal protest against Soviet domination, or an aspiration for national self-identification. Moreover, Belarusians, like most of the nations of the Former Soviet Union, had little understanding of market economy values, as, unlike CEE countries, Soviet

\footnotetext{
${ }^{3}$ For an overview of empirical studies on financial repression see Fry (1995).
} 
domination lasted for nearly seven decades, and the first major political and economic reforms did not start until Perestroika in 1986.

Thus the Belarusians, as well as the Belarusian authorities represented by the remnants of the Communist elite, were not ready for a political-cum-economic radical transformation of their society. Neither were the latter willing to do this. They were keen on preserving the status quo including a single Rouble zone and an assured supply of oil and gas at subsidised internal Russian prices. This helped Belarus avoid the early transition decline in production that was typical of the region, but did not prevent a recession in 1993-1994 (Silitski 2002, Korosteleva 2004).

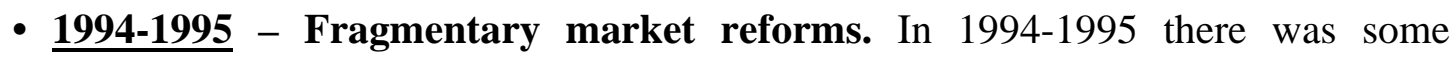
liberalisation of the domestic financial market: positive real interest rates; allocation of about 80 per cent of short-term loans through market credit auctions in the Interbank Exchange Stock; tightened monetary expansion; and reduced reserve requirements. These measures plus a fixed exchange rate (as an anchor of stabilisation policy) helped to bring inflation down from a 2,221 per cent in 1994 to 53 per cent in 1996, consequently restoring the credibility in the Belarusian rouble and providing the preconditions for an increase in the share of deposits of households in total deposits (Korosteleva 2004).

\section{- 1996-2000 - Pervasive state control over the economy introduced to sustain the} Belarusian economic model. Due to his fear of losing popularity among people as a consequence of a decline in the standard of living, President Alexander Lukashenko reversed the reforms in 1996-2000 and introduced the elements of the repressed economy (Korosteleva 2004). Thus administrative reallocation of resources and administrative interest rates control were supposed to keep state-owned enterprises afloat and boost output through stimulating aggregate demand. Timely wage payments, bans on layoffs and periodic increases in nominal wages were to target the social sector and, therefore, to assure Lukashenko's electoral support. Finally, creation of rent-seeking mechanisms through licensing of certain economic activities, rationing access to cheap natural resources, introduction of restrictions on foreign exchange and a multiple exchange rates policy aimed at satisfying the interests of the political elite. Repression of the financial sector was placed at the centre of this policy, to make financial intermediaries serve the government needs. 


\subsection{Banking Sector}

In 1996 the practice of challenging lax credits to support loss-making enterprises was re-established through regaining state control over a banking system that had by that time been partly liberalised. ${ }^{4}$ The state direction was realised through 1 ) renationalisation of the banking sector and 2) legitimising the subordination of the NB.

Re-nationalisation began with merging the state-owned National Savings Bank and the commercial Belarusbank in August 1995. Belarusbank had a bad loan portfolio that could be cleared by merging with a healthier bank. Thus at first glance this consolidation appeared to be a bailout for Belarusbank at first glance. However, at the same time it turned Belarusbank into the state agent in channelling soft loans to the real sector.

The further re-nationalisation proceeded with Presidential decree No.209 of May 24 ${ }^{\text {th }}, 1996$ 'On measures on Regulation of Banking Sector of the Republic of Belarus'. It approved the list of banks servicing the state programmes. Moreover, it envisaged the measures to be undertaken by the government to increase its share and the share of state-owned enterprises in the statutory funds of the banks. Finally, it required the wages of bank clerks to be paid according to the tariff system for the public sector. On October $2^{\text {nd }}, 1996$ the Council of Ministers issued Resolution No.647/9 that officially defined six large banks as the state agents in servicing prior state socio-economic projects and government debt. Afterwards they were termed as 'system-forming banks' (hereafter, SF banks). This term primarily means the high importance of these banks for the economy of Belarus. These banks control over 90 per cent of total assets, 90 per cent of enterprise lending, almost 100 per cent of lending to households, and their capital accounts for 77 per cent of total banking capital (Korosteleva 2004). Thus the banking sector in Belarus is highly concentrated and monopolised by the state. ${ }^{5}$ As of January 2001, non-state ownership in banking was just 12 per cent compared to 45 per cent ${ }^{6}$ in 1995.

\footnotetext{
${ }^{4}$ For a detailed description of the liberalizing reforms see Korosteleva 2004.

${ }^{5}$ The term 'state monopolisation' is used here to show that the banking sector is mainly represented by the six system-forming banks which are largely state-owned and which have a dominant position in the market. However, to be more precise, each of the six banks operates in a specific market segment and, in these specific segments, there is no the competition between the banks, which means that each bank has a monopoly over the market segment in which it operates.

${ }^{6}$ IMF 1995, p.33.
} 
For the National Bank edicts in 1998 and 2000 gave the President the authority to appoint and remove the chairperson and Board of Directors of the NBB and to suspend and revoke any of its decisions (Korosteleva 2004). Thus, monetary authorities were left with little room for manoeuvre in formulating and implementing their policies.

The depth of financial intermediation is shallow. Domestic credit provided by the banking sector to the economy accounted for only 21 per cent of GDP in 2003, far below many CEE countries (see figure 1). A loose monetary-credit policy, aiming to keep real sector afloat, drained bank financial resources because many loans were never repaid and inflation eroded the real value of bank deposits and capital, thus leading to serious liquidity problems and undercapitalization of the banking sector. Priority financing of loss-making state-owned enterprises triggered problems of adverse selection and moral hazard. Thus, access to credit by 'good borrowers', who deserved to get it by all means and were ready to pay a competitive interest rate, was restrained by liquidity constraints and low capitalization of the banking sector. At the same time, state-owned enterprises, correctly believing they were too important to fail, took bank loans for granted, often failing to repay them and expecting new bank loans to bail them out.

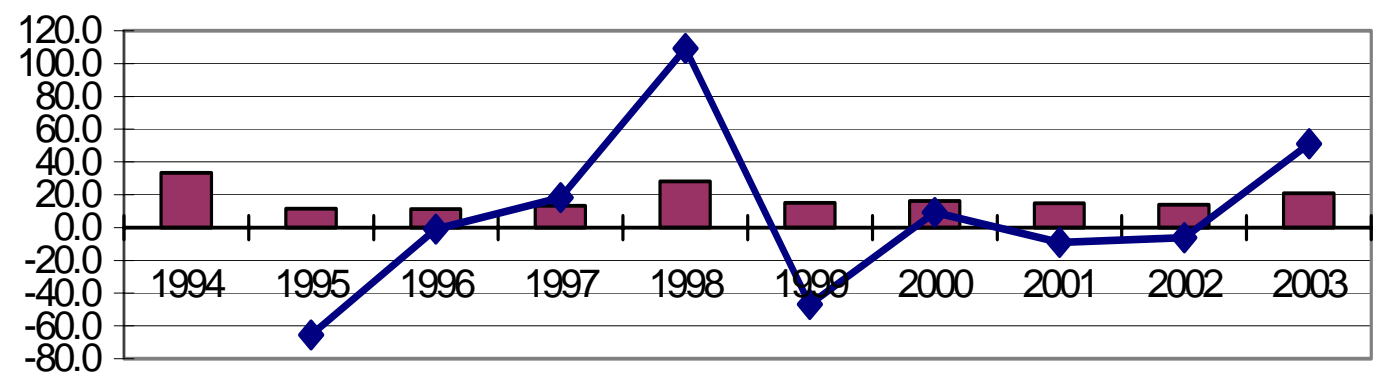

bank credits as a \% of GDP $\neg$ Percentage change in bank credits to economy

Figure 1: Bank credits as a per cent of $G D P^{7}$

In summary, assigning the central role in maintaining the Belarusian economic model to the banking system, the government halted banking reforms in the banking sector and reinforced state control. Re-nationalisation of specialised banks, subordination of

\footnotetext{
${ }^{7}$ Authors' calculations on the data provided by the National Bank of the Republic of Belarus (National Bank of Belarus 2000a (January), 2000b (January), 2001, 2002, 2003).
} 
the National Bank to the government, centralisation and state monopolisation made the banking system impotent and turned it into a tool of control.

This has occurred in a system with very shallow capital markets, where finance is solely bank-based.

\subsection{Financial restraints}

The main ideas which laid the basis for Belarusian economic development in the late 1990s, can be summarised as follows:

I. By disregarding the inflationary nature of money growth, the Belarusian authorities stressed the importance of revitalising the practice of lax credits to economic agents that were believed to facilitate increase in output, as the decline in it, according to them, was solely attributable to enterprises' shortage of money.

II. The NBB resorted to the policy of high reserve requirements in order to target excess liquidity resulting from the expansionary monetary-credit policy. In turn, higher reserve requirements increased the government's gains from seigniorage, that flowed mainly from the expanding monetary base.

III Recognising the negative output effect of high real interest rates the government favoured administratively controlled interest rates to make bank resources more accessible to enterprises.

IV. By seeing speculation as a driving force behind the BRB depreciation, the Belarusian authorities believed in their ability to ensure the BRB's stability by setting the nominal exchange rate administratively and by restricting the access of noncritical importers to the foreign exchange market ${ }^{8}$.

These ideas resulted in the implementation of four main financial repressionist policies, namely: directed credits and preferential loans to key sectors; high reserve requirements; a policy of negative real interest rates; and a policy of multiple exchange rates which together formed the centre of the Belarusian strategy of economic development.

\section{Directed credits policy}

Although directed credits were continuously exercised from the beginning of transition, they were first officially defined in 1998 in the 'Main requirements for

\footnotetext{
${ }^{8}$ Rusakevich 2002.
} 
banks to use directed credits'9. Directed credits were accordingly defined as loans designed for mainly supporting the agricultural sector ${ }^{10}$ and house construction. The traditional way of channelling these credits was through the SF banks, which were government agents in servicing social-cum-economic oriented programmes. The loans were channelled within open credit lines at interest rates varying between one fiftieth and one half of the refinancing rate (see below).

The aforementioned document envisaged also the use of bank-agents or 'system-forming' banks in serving other governmental programs of 'high priority' on 'favourable terms' ${ }^{11}$ at the expense of banks' own/attracted capital. However, in terms of constant liquidity problems of the banking system as a result of their financing of low-yield projects the NBB had to provide them with the necessary resources. Thus, financing with the use of banks' resources still to a great extent remained inflationary with the only difference that current banks' loans were financed by the followed (lagged) NBB emission.

There exists evidence that many of the issued loans were not repaid on time and were always rolled over, often even without accruing interest during the period of loan prolongation. Thus, Presidential Decree No.96 (3 March 1998) ${ }^{12}$ said that liabilities of collective and state farms (kholkhozy and sovkhozy), and other agricultural enterprises as of December 1997 were extended and due to be repaid from 1 January 2000 to 1 September 2000. The same Decree authorised SF banks to issue new credits to these enterprises in 1998, which contradicted the aforementioned 'Main requirements for banks to use directed credits'. The latter says,

'Banks, defined to finance preparation and carrying out of sowing campaigns, issue short-term loans within credit lines open for these purposes by the NBB to financially stable collective farms and other agricultural enterprises and organisations, which do not have over-due loans with the banks issued to them earlier'. ${ }^{13}$

\footnotetext{
${ }^{9}$ NBB Resolution No.6.2 (11 February 1998) (Konsul’tant Plyus: Belarus [CD-Rom] 2002).

${ }^{10}$ Loans for agricultural sector were usually issued for the purposes of creating state grain reserves; purchase and delivery of agricultural products, and financing sowing/harvesting campaigns.

${ }^{11}$ The term 'on favourable terms' means that the lending interest rate was only half of the refinancing rate.

${ }^{12}$ Konsul'tant Plyus: Belarus [CD-Rom] 2002.

13 Paragraph 1.1 of the 'Main Requirements for banks to use directed credits', No. 6.2, adopted by the NBB on 11 February 1998 (Konsul'tant Plyus: Belarus [CD-Rom] 2002).
} 
Banks' margins in connection with directed credits or preferential loans were often set within a 1-2 per cent limit. In this case, the concept of margin was practically meaningless as 1) it was negative in real terms and could not even cover banks' costs of servicing credit; 2) as mentioned above, interest payments were paid occasionally (on loans to house construction and industry), if at all (in the agricultural sector); 3) over time these loans became outstanding and were rarely recovered. In other words, these loans were potentially bad debts. In this case, the National Bank or the Ministry of Finance applied debts-for-equity swap schemes to these banks, so increasing state ownership in them. This swap appeared to improve banks' performance (bad debts decreased whilst capital increased), but in reality it was an artificial growth of capital.

These directed or emission credits as a way of the state reallocating financial flows, particularly via channelling credits directly from the NBB to commercial banks, can be regarded as quasi-budget expenses. This is why Belarus was among the limited number of post-communist countries that managed to keep its budget deficit at level less than 3 per cent of GDP.

On banks' refinancing mechanisms, it is interesting to note that while in 1995 80 per cent of the credits were reallocated through market actions ${ }^{14}$, after 1996 they became allocated administratively. Following the NBB Regulation rules No.93 (23 August 1996) $)^{15}$, banks were mainly refinanced at the interest rate set by the Council of Directors of the NBB that depended on a official refinancing rate. The official rate was the announced refinancing rate, at which a small amount of the credit market had been served. The actual refinancing interest rate was the rate at which the National Bank granted credits. As noted by Rusakevich (2002, pp. 19-20) this rate was composed of the following main interest rates:

1. A highly privileged rate on directed credits granted for the housing construction programme - usually one tenth of the announced refinancing interest rate. With inflation between 63.9 per cent and 293.7 per cent p.a. in 1997-1999, this

\footnotetext{
${ }^{14}$ Credit auctions first were introduced in 1993. The volumes of loans allocated through credit auctions were set in Main Directions of monetary-credit policy for each year and were reconsidered quarterly depending on the tasks of liquidity regulation of monetary market. Following Regulation Rules adopted by the NBB, No.71 (5 May 1995) under conditions of high inflation loans were issued only for $7-14$ days. Two types of auctions were envisaged: 1) "rate tender" - bids for fixed amount of money. All demands, starting with a tender offered the highest interest rate and ending with a tender who still fits the set credit limit, were satisfied; 2) at a single cutting off rate - the same procedure as in 1), but all demands were satisfied at a single cutting off rate

${ }^{15}$ Konsul'tant Plyus: Belarus [CD-Rom] 2002.
} 
rate was only 5 per cent $\mathrm{pa}^{16}$ and credit was granted on the condition that it was to be repaid within 40 years $^{17}$.

2. A privileged rate on the majority of directed credits to agriculture. In 19972000 this was half of the announced rate.

3. The official refinancing rate which was mainly used as a rate of return on government bonds $(\mathrm{GKO})$ of the first circulation.

4. Rates on market instruments of short-term financing (Lombard and overnight credits), which were, as a rule, higher than the announced refinancing rate. However, these rates were still administratively set and were not usually much above the official refinancing rate. For example, while the official refinancing rate was 36 per cent p.a. in September 1997, the Lombard rate was set in the range 40-45 per cent p.a.

The fact that the actual refinancing rate was beneath the deposit rate encouraged banks to appeal for cheap NBB credit resources ${ }^{18}$ rather than to attract private sector deposits.

Financing of priority enterprises by commercial banks 'on favourable terms' has surged particularly since 1999, after the authorities expressed their intention to increase the use of commercial banks' resources in financing economic agents. In fact, official statistics suggest that, in 2000, directed credits to the house construction and to the agricultural sectors were fully replaced with preferential credits issued by commercial banks. However, this did little to change the heart of the problem, as inflationary financing was still in place ${ }^{19}$. Therefore, the figures on direct credits presented in table 1 do not reflect the full extent of inflationary financing of the economy as they do not count for preferential loans ${ }^{20}$.

\footnotetext{
${ }^{16}$ Interest payments were envisaged to be paid only three years after the loan had been issued.

${ }^{17}$ When the house construction programme was launched in 1996 (Presidential Directive No.516 (22 December 1995) (Konsul'tant Plyus: Belarus [CD-Rom] 2002) loan was initially granted for 20 years. Since 2000 JSSB "Belarusbank" has been authorised to finance only 75 per cent (95 per cent still in rural areas) versus 90 per cent in 1995-99 of the cost of house construction for no more than 20 years (40 years in rural areas) under 10 per cent (5 per cent in rural areas) p.a.

${ }^{18}$ The NBB set refinancing limits every year for each bank individually. These limits were often reconsidered during each year always towards increase.

${ }^{19}$ There should be noted that over the recent years this practice has been gradually replaced with new, market-based, schemes of banks' refinancing, amongst which 'repo' operations and Lombard credits could be named. It has had positive effect on macroeconomic stabilisation.

${ }^{20}$ Unfortunately, the lack of transparency in banking statistics does not allow collecting data on preferential loans.
} 


\begin{tabular}{|l|c|c|c|c|c|}
\hline $\begin{array}{l}\text { Share of each form of refinancing in total volume } \\
\text { of refinancing, } \%\end{array}$ & $\mathbf{1 9 9 6}$ & $\mathbf{1 9 9 7}$ & $\mathbf{1 9 9 8}$ & $\mathbf{1 9 9 9}$ & $\mathbf{2 0 0 0}$ \\
\hline Directed credits & 65.3 & 53.5 & 58.7 & 45.1 & 0 \\
\hline including: & & & & & \\
\hline \multicolumn{1}{|c|}{ house construction } & N/a & 25.7 & 32.4 & 33.9 & 0 \\
\hline agricultural sector & N/a & 27.2 & 23.4 & 9.3 & 0 \\
\hline other & & & & 1.9 & \\
\hline Lombard credits & 8.5 & 1 & 0 & 14.7 & 15.8 \\
\hline Overnight credits & & & & & 37.4 \\
\hline $\begin{array}{l}\text { Purchase of government securities (including 'repo' } \\
\text { operations) }\end{array}$ & 12.8 & 14.6 & 28.4 & 22.9 & 18.7 \\
\hline Swap transactions & 13.4 & 29.9 & 11.3 & 15.1 & 5.3 \\
\hline Other forms refinancing & 0 & 1 & 1.6 & 2.2 & 22.8 \\
\hline Total: & 100 & 100 & 100 & 100 & 100 \\
\hline
\end{tabular}

Table 1: Structure of banks' refinancing ${ }^{21}$

According to the NBB all forms of refinancing, excluding directed credits, are defined as market forms of refinancing. But none of these credits were allocated on a true market basis, and interest rates were wholly administrative.

Alongside directed credits and preferential loans schemes, the NBB consistently monetised budget deficit ${ }^{22}$. So, it is worth comparing data on NBB credits to the government with figures on the actual budget expenditures in part of supporting priority sectors of economy (agriculture, house construction and industry) to see to what extent the latter could potentially be covered by the NBB emission.

In fact, conceptually there was not much difference between loans granted to the government to finance priority sectors of the economy and the NBB directed credits. The National Bank issued loans to the Ministry of Finance, which in turn reallocated them between the SF banks. It is also worth noting that from 1999 it was very common for SF banks to finance 'strategic' enterprises the actual refinancing rate and for the government to compensate banks for half of the refinancing rate due to be paid by 'strategic' enterprises. In fact, this compensation was meant to be paid from the Republic's budget (section on 'Subsidies to state enterprises and organisations and other subsidies'). A similar financing scheme, introduced around the same time, envisaged compensation of 50 per cent of the refinancing rate to SF

\footnotetext{
${ }^{21}$ NBB material given to the author by the Head of Foreign Exchange Analysis and Forecasting Division of the NB during our meeting in March 2003.

${ }^{22}$ As a matter of fact monetisation of government debt was banned in Russia since 1995, while in many CEECs - at a even earlier stage of transition.
} 
banks (also to be paid from the Republic's Budget) that issued loans to 'strategic enterprises' at half of the refinancing rate. Compensation was not given on a regular basis.

\begin{tabular}{|c|c|c|c|c|c|}
\hline & 1996 & 1997 & 1998 & 1999 & 2000 \\
\hline $\begin{array}{l}\text { Total expenditure, } \\
\text { mln. BRB }\end{array}$ & 63345.7 & 135865.3 & 249577.5 & 1142843 & 3181146 \\
\hline \multicolumn{6}{|l|}{ including: } \\
\hline Agricultural sector & 1996.0 & 4222.9 & 9799.0 & 37253.6 & 87050.9 \\
\hline House construction & 2489.0 & 6133.9 & 13107.3 & 81387.7 & 248081.6 \\
\hline Industry & 675.4 & 1730.4 & 3747.9 & 20409.9 & 34735.6 \\
\hline Budget deficit/surplus & -3645.9 & $\begin{array}{l}-6738.5 \\
\end{array}$ & -9995.5 & -87935.7 & $\begin{array}{l}-1747.3 \\
\end{array}$ \\
\hline $\begin{array}{l}\text { Total expenditures on the } \\
\text { aforementioned } \text { budget } \\
\text { articles, as \% of total } \\
\text { government expenditure }\end{array}$ & 8.1 & 8.9 & 10.7 & 12.2 & 11.6 \\
\hline $\begin{array}{ll}\text { NBB financing } & \text { of } \\
\text { government deficit (plan) }\end{array}$ & 1860.00 & 3375.0 & 6075.3 & 28700 & 75875.9 \\
\hline $\begin{array}{l}\text { NBB financing of budget } \\
\text { deficit (actual) }\end{array}$ & 7484 & 12437.9 & 48440.7 & 138682.7 & 261058 \\
\hline $\begin{array}{lcc}\begin{array}{l}\text { Percentage } \\
\text { government }\end{array} & \begin{array}{c}\text { change } \\
\text { financing }\end{array} & \text { in } \\
\text { NBB } & & \\
\end{array}$ & & 66 & 289 & 186 & 88 \\
\hline $\begin{array}{l}\text { Total expenditures on the } \\
\text { aforementioned } \\
\text { articles, as \% of Nget } \\
\text { financing (actual) }\end{array}$ & 69 & 97 & 55 & 100.3 & 142 \\
\hline
\end{tabular}

Table 2: Actual government expenditures in part of financing agricultural sector, house construction and industry ${ }^{23}$

Because of the low capitalisation of the banking system ${ }^{24}$ and the enormous investments that some projects required (for example, to finance capital replacements in oil refinery companies in Mozyr, or a potassium producer, 'Belaruscalii'), the authorities often authorised more than one SF bank to participate in the financing of these projects. These 'consortia loans' were mainly denominated in foreign currency under government guarantee. This meant the loan repayment in BRB at the official

\footnotetext{
${ }^{23}$ Author's calculations on the NBB data (National Bank of Belarus 2000a (January), 2000b (January), 2001, 2002, 2003). Figures on NBB financing of budget deficit were derived from the Law 'On Budget of the Republic of Belarus for 1996', No. 279-XIII (19 April 1996), the Law 'On Budget of the Republic of Belarus for 1997', No. 20-3 (21 February 1997), the Law 'On Budget of the Republic of Belarus for 1998', No.107-3 (29 December 1997), the Law 'On Budget of the Republic of Belarus for 1999', No.245-3 (24 February 1999), the Law 'On Budget of the Republic of Belarus for 2000', No.367-3 (31 January 2000) (Konsul'tant Plyus: Belarus [CD-Rom] 2002).

${ }^{24}$ As at 2001 the level of capitalisation accounted only for 4.7 per cent of GDP.
} 
exchange rate which was around 60 per cent lower than the market exchange rate. Moreover, there exists evidence that these loans were not repaid on time and the government often extended the guarantee.

\section{Interest rates controls}

Belarusian credit policy has primarily been based on the policy of administratively controlled interest rates, in which the official refinancing rate was always used as a yardstick. But available official records of interest rate controls (especially lending and deposit rates) are very limited. The legal database holding most of the records on bank regulation contains some fragmentary information on the use of deposit rate floors, margin controls, and lending rate ceilings (primarily for directed credits). Lending interest rates ceilings on loans of commercial banks are only directly mentioned in 'Main Monetary and Credit Guidelines of the Republic of Belarus for $1994^{25}$ and in the Banking Code ${ }^{26}$. The former document states that 'until the market mechanism of economic regulation is in place, the NBB has the right to carry out a policy of temporarily imposing lending rates ceilings both on directed credits and on the loans of commercial banks to the real sector'. The second document adds: 'In exceptional cases the NBB has the right to set minimum/maximum lending interest rates for commercial banks in their operations with individuals and legal entities' (paragraph 52). In fact many instructions, including those regulating interest rates, came in the form of the written letters for the 'internal use' of the NBB or in the form of NBB oral 'recommendations'. Most of the information on interest rates ceilings, particularly on lending interest rates ceilings, is confidential (confirmed by the Head of Foreign Exchange Analysis and Forecasting Division of the NB in March 2003).

Following the Roubini and Sala-i-Martin's approach (1992) in the absence of reliable information on the actual controls, the level of real interest rates can be useful in evaluating the degree of the interest rate repression (figure 2).

\footnotetext{
${ }^{25}$ Approved by the National Bank of Belarus, Letter No.20-94 (2 June 1994) (Konsul’tant Plyus: Belarus [CD-Rom] 2002).

${ }^{26}$ Adopted by the House of Representatives, Banking Code No.441-3 (25 October 2000) (Konsul'tant Plyus: Belarus [CD-Rom] 2002).
} 


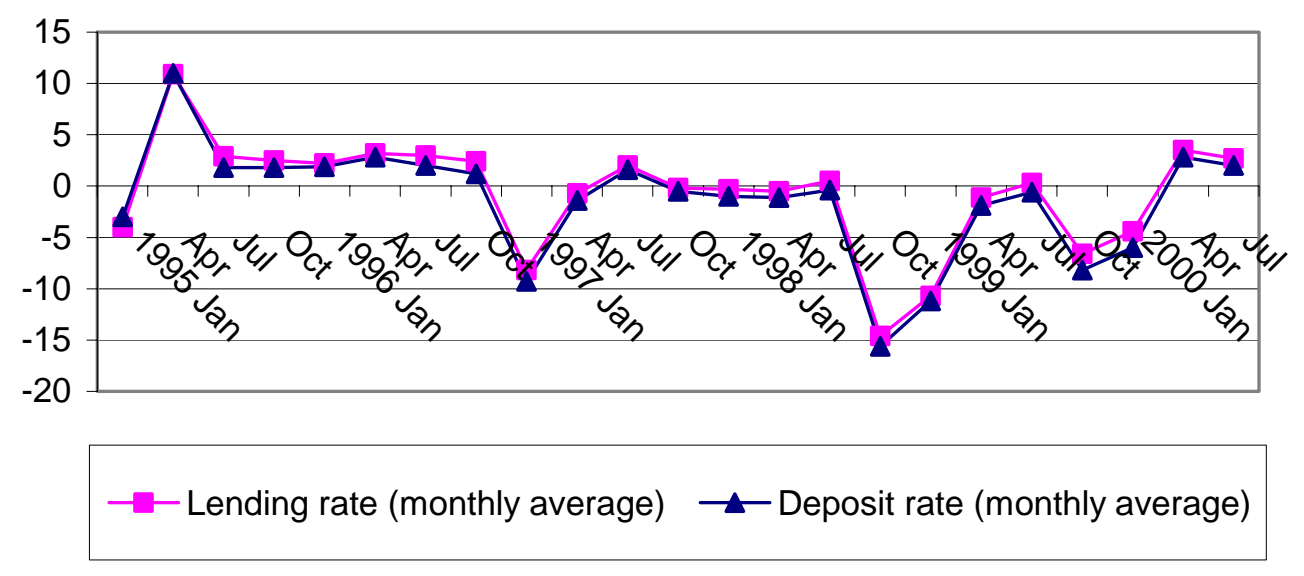

Figure 2: Real lending and deposit interest rates ${ }^{27}$

There is no documentary evidence of deposit interest rate ceilings. However, as in the case of lending interest rate ceilings, figure 2 speaks for itself. Moreover, as Fry argued, 'in the absence of deposit rate ceilings, the FR tax may still be borne by depositors to the extent that banks are required to use their own resources to acquire non-reserve assets that yield net returns below the world market interest rate' (Fry 1995, p.6). Thus, by being obliged to issue loans at interest rates being low or negative in real terms or to invest in government bonds with the real yield being proxied by the real announced refinancing rate, commercial banks did not have much option in offering comparable returns on deposits.

In conclusion, interest rates never operated as an instrument of efficient allocation of funds. Moreover, very high interest rates, had an adverse selection effect on borrowers - encouraging investment with low returns (agriculture, house construction and state enterprises of industrial sector) - and crowding out highyielding private sector projects.

\section{Reserve requirements}

The policy of unprecedented monetary-credit expansion created excess liquidity in the market. The paradox was that some of the SF banks (particularly Belarusbank and Agroprombank) were contracting liquidity, while others had it in excess. Thus, the

\footnotetext{
${ }^{27}$ Authors' calculations on the data provided by the National Bank of the Republic of Belarus (National Bank of Belarus 2000a (January), 2000b (January), 2001, 2002, 2003).
} 
NBB resorted to the policy of higher reserve requirements to be able to regulate any 'market' imbalances.

De Melo and Denizer (1997) in their work on monetary policy during transition use 12 per cent or less as a yardstick for maximum reserve requirements for transition economies to be recognised as market-oriented.

In Belarus, while never exceeding 30 per cent and falling in recent years, reserve requirements were above 12 per cent for most of the period.

Despite being not so heavy in relative terms, the policy of high reserve requirements can still have a greater negative effect on financial sector than would be expected. With high inflation, increasing reserve requirements has a magnified effect, expanding the wedge between deposit and lending rates (Fry 1995, p.43). Thus, under de-facto controlled lending rates, deposit rates could have been potentially negligibly low. Hence the authorities' decision was to impose deposit floors in 1996-1999.

\section{Multiple exchange rates}

Exchange rate policy can be divided into three main periods: 1993-4, with a floating rate, 1995-6 with a fixed rate, and 1996-2000, with a 'planned devaluation' system² ${ }^{28}$ The latter relied on multiple exchange rates. There were six exchange rates in 19962000: the official NBB rate for tax and accounting purposes; for the obligatory surrender of 30-40 per cent of exporters' earnings (corresponds to stock market exchange rate (main session)); the stock market exchange rate (additional session) for the obligatory surrender of an additional 10 per cent of exporters' earnings; the nonstock market exchange rate or commercial rate for inter-bank settlements; the nonresident market exchange rate (quotations of the Central Bank of Russia, the exchange rate 'set' by commercial Belarusian banks for cash currency sale to individuals; the black market rate. In fact, since the official exchange rate was on average 60 per cent lower than the market exchange rate, by surrendering their 30-40 per cent of earnings at the official exchange rate exporters were paying an additional 15 per cent $\operatorname{tax}^{29}$.

In 1999 the authorities began moves to a uniform and stable exchange rate and convertibility of the Belarusian rouble for current account operations. Indeed, at the

\footnotetext{
${ }^{28}$ The mechanism of rate's formation on a market basis actually began to work since 4 January 1993, when the NBB introduced the quotation of the Belarusian Rouble in hard currencies.

${ }^{29} 15$ per cent $=.40 * .60 / 1.60$ (Nuti 1999, p.8).
} 
end of 1999 the NBB liberated the exchange rate set by commercial banks for cash currency sale to individuals. By September 2000 the official exchange rate was devalued to the market level, which, in turn, was maintained by partial 'sterilisation' foreign exchange movements. After the unification the exchange rate has remained relatively stable.

We discuss policy implications below.

\section{Policy implications}

All four highlighted policies had a magnified negative effect on economic development. For example, the expansionary policy of directed credits and preferential loans, targeting, in the first place, 'strategic' (state) enterprises, resulted in high inflation and devaluation of the Belarusian rouble. The inflationary financing reduced, and the subsequent finance shallowness reduced growth. Although negative real interest rates boosted aggregate demand, an inability to stimulate domestic saving and therefore private fixed investment imposed constraints on its sustainability. Figure 3 shows the change in financial depth, defined in a narrow sense as the ratio of total rouble denominated bank deposits to GDP.

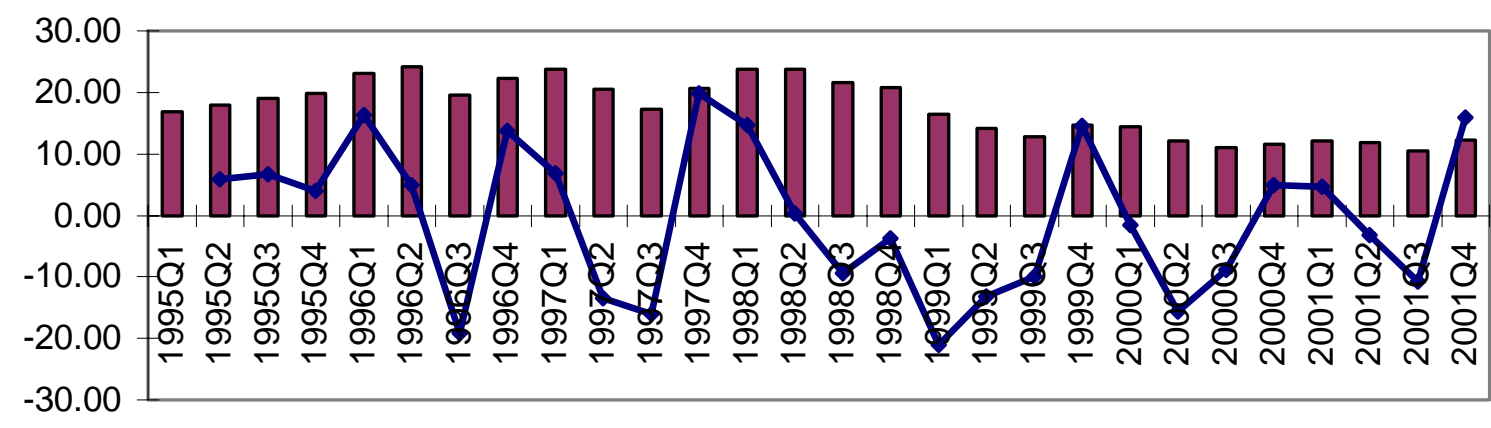

Financial Depth $\rightarrow$ Percentage change in Financial Depth ratio over the previous period

Figure 3: Financial depth, measured as a ratio of quarterly average rouble bank deposits to GDP nominal ${ }^{30}$

Figure 3 shows the ratio of total rouble deposits to GDP never exceeded 25 per cent, implying that, as a potential source of investment, domestic deposits played a fairly insignificant role in financing the economy. In fact, as only 70 per cent of the

\footnotetext{
${ }^{30}$ Authors' calculations on the data provided by the National Bank of the Republic of Belarus (National Bank of Belarus 2000a (January), 2000b (January), 2001, 2002, 2003).
} 
economy was monetised, this is not surprising. The financial depth ratio decreased from 69 per cent of GDP in 1990 to 10 per cent in 2001.

As inflation led to devaluation the Belarusian rouble lost its credibility, and dollarisation spread. ${ }^{31}$ With the ratio of foreign currency deposits to broad money exceeding 30 per cent for most of the period, Belarus can be classified as a highly dollarised economy.

So, the policy of multiple exchange rates was an instrument to hold down the price of foreign exchange. In turn, it created the deficit of foreign currency in the official market that stimulated the development of the shadow market. The overvalued Belarusian rouble encouraged importing that spilled into the current account deficit.

Moreover, excess demand for foreign currency prompted the authorities to impose foreign exchange and cross-border payments restrictions. The latter as well as high inflation shrank enterprises' nominal assets and induced them to use alternative financial mechanisms and barter operations. According to the official data, nonmonetary operations held a steady share of 30 per cent in total sales during 19972002. As well as barter operations accounting for the majority of non-monetary operations, enterprises have been using promissory notes and commercial credit as substitutes for bank money. According to some experts, extensive reliance on barter appears as key factor leading to resumed growth in the late 1990s (TACIS 1999).

But like the overall financial strategy, the consequent financial disintermediation is damaging in the long run.

\section{Evaluating an impact of financial restraints on financial development}

In order to examine the impact of FR on financial depth I estimate equation (1) replicating the model that Demetraides and Luintel (1997) use to examine the Indian case of FR:

$$
\mathrm{LFD}_{t}=\alpha_{o}+\alpha_{1} L Y_{t}+\alpha_{2} R_{t}+\alpha_{3} F R I_{t}+\alpha_{4} D E V_{t}+u_{t}
$$

where LFD is the log of financial depth, measured as ratio of bank deposits to nominal GDP;

LY is the log of the real GDP per capita;

\footnotetext{
${ }^{31}$ The term 'dollarisation' serves as shorthand for the use of any foreign currency.
} 
$\mathrm{R}$ is the real deposit interest rate;

$\mathrm{DEV}$ is the rate of devaluation of domestic currency;

FRI is a summary measure of financial repression

I introduce the DEV variable to proxy dollarisation. To construct this series it is necessary to recall the multiple exchange rate regime operating from 1996 to 2000. Since there is no reliable information on the volume of currency transactions carried out for each separate exchange rate, I follow the National Bank of Belarus' method to overcome this problem. Thus the nominal exchange rate is computed as a weighted average of official (15 per cent) and market end-of-month exchange rates (85 per cent $)^{32}$. With financial depth measured as total rouble deposits to nominal GDP, the coefficient of DEV is expected to have a negative sign.

As noted earlier, the widespread use of barter and other non-monetary operations in transactions between economic agents was another consequence of FR policies. But, it is impossible to address this problem due to the lack of information on barter transactions.

Our empirical analysis has two objectives. First, to examine whether financial policy can be described as financial repression, and if so, what were the effects on financial deepening. Second, to uncover the interactions between financial depth and economic growth.

The initial hypothesis is that FR took place in Belarus in 1996-2000 and had a negative influence on financial depth and growth. So the coefficient on FRI in (1) is expected to be negative and significant.

\subsection{Methodology and data}

The monthly data run from May 1995 to December 2002. The sample is chosen on the basis data availability and the desire to incorporate both the 1996-2000 repression and the fragments of partial FL in 1995 and in 2001-02.

Financial depth is measured by total bank deposits nominated in roubles to nominal GDP. Data on rouble bank deposits, 6-month nominal deposit and lending interest rates (the latter is needed to construct the index of FR), official and marketdetermined parallel exchange rates were obtained from the National Bank of Belarus. Real deposit/lending rates are defined as the nominal deposit/lending interest rate

\footnotetext{
${ }^{32}$ These proportions are based on the NBB approximate evaluation of the volume of transactions that are carried at each exchange rate.
} 
minus the current rate of inflation. The rate of inflation is defined as the percentage change in a consumer price index (CPI). Data on the monthly rate of inflation and monthly real GDP were provided by the Belarusian Research Centre of Institute of Management and Privatisation, which in turn obtained the data from the Ministry of Statistics and Analysis. The real GDP per capita series is calculated by dividing the aggregate series by population. The financial depth and real GDP per capita are in logarithmic form.

To avoid multicollinearity and a reduction in the degrees of freedom we use a summary index of FR (FRI) instead of introducing each repressionist policy individually. FRI is a simple arithmetic average of all policy variables. Normalising policy variables (subtracting the mean and dividing by the standard deviation) preceded the construction of this index.

The index is comprised of series on the following repressionist policies.

i. Deposit rates ceiling;

ii. Lending rates ceiling;

iii. Directed credit schemes;

iv. Reserve requirements

Because of the fragmentary nature of official data recording ceilings on deposit and lending interest rates, the first two controls are measured on the basis of Agarwala's approach (1983). ${ }^{33}$ In the latter, the degree of interest rate repression is defined as being high when real interest rates were less than minus 5 per cent per annum; medium when they varied between 0 and minus 5 per cent per annum; and low/absent when real interest rates were positive. Respectively, values 3, 2 and 1 are assigned to a dummy variable denoting FRI in Agarwala's work. In Belarus, the annual real interest rate sometimes exceeded minus 200 in 1995-2002. Thus, in order to capture the severity of interest rates repression, we use a different scale of values for the dummy variable. It is zero when interest rates are positive; one when they are between 0 and minus 20; two, between minus 21 and minus 40 and so on, up to a value of eleven when real interest rates exceed minus 200.

The 'directed and preferential credits' repression instrument reflects the intensity of the program. The dummy variable is zero for no directed credit; and one,

\footnotetext{
${ }^{33}$ As Roubini and Sala-i-Martin's (1992) work suggests, the distortion dummy defined as dichotomous, taking the values zero when financial restraints are present or one when they are not, may not capture the severity of financial repression, producing statistically insignificant results.
} 
two and three when the share of directed and preferential loans reach 20 per cent, 2140 per cent, and over 40 per cent, respectively, of total bank credit. ${ }^{34}$ As only annual data on the directed credit program are available, some subjective judgement was used to construct this variable. Monthly data were derived on the basis of annual data, taking into account the seasonal pattern of agricultural subsidies and the even annual distribution of house construction loans. ${ }^{35}$

Finally, the required reserve ratio is a weighted average of the reserve requirements rate on demand and time deposits, with their shares in total deposits nominated in BRB as weights. Data on the required reserve ratio was provided by the NBB.

The arithmetic average FR index was linearly transformed to take the value zero in May 1995 and to be scaled by 100. It is strongly positively correlated with each policy variable.

\subsection{Empirical results}

From the unit root analysis only the financial depth variable appears to be first differences stationary. Therefore, after first differencing LFD, OLS is used. Other variables enter the equation in levels. In particular, an Autoregressive Distributed Lag (ADL) model is used to capture the dynamics. The estimated coefficients of the explanatory variables are interpreted as their impact on financial deepening during the evaluation period. Unlike cointegration techniques, the ADL model will not allow us to draw any separate inferences about the short-run and long-run effects that the explanatory variables exerted on financial deepening. A Granger-Causality test showed that real GDP per capita, the financial repression index, the real deposit interest rate and the rate of devaluation series were all exogenous. The ADL model is specified as follows.

$$
\begin{aligned}
& L F D_{t}=\alpha_{0}+\alpha_{1} t+\alpha_{2} L F D_{t-1}+\alpha_{3} L F D_{t-2}+\ldots+\beta_{1} L N Y s a_{t}+\beta_{2} L N Y s a_{t-1}+\ldots+\delta_{1} F R I_{t}+ \\
& +\delta_{2} F R I_{t-1}+\ldots+\phi_{1} R_{t}+\phi_{2} R_{t-1}+\ldots+\mu_{1} D E V_{t}+\mu_{2} D E V_{t-1}+\gamma_{1} D U 98+u_{t}
\end{aligned}
$$

\footnotetext{
${ }^{34}$ See Demetriades and Luintel (1997).

${ }^{35}$ Both sectors were major recipients of directed credits.
} 
The expected rate of devaluation in the equation is proxied by the actual rate of devaluation ${ }^{36}$.

The appropriate lag-length is chosen by the general-to-specific approach advocated by Hendry (1995). Given our monthly data we start with 12 lags and then use unit reductions to achieve the highest values of AIC and SBC (model selection criteria) consistent with white noise residuals. This results in the choice of an ARDL $[(1,12), 2,(1,3) 1,1]$ specification, where $(1,12)$ means that only the $1^{\text {st }}$ and the $12^{\text {th }}$ of $\triangle$ LFD series are included in the equation, as they are the only ones that appear to be statistically significant. Their inclusion is required to overcome a problem of serial correlation in the residuals. The choice of the $1^{\text {st }}$ and the $3^{\text {rd }}$ lags for the FRI series can be similarly explained. The results of the model estimation are presented in table 5.

\begin{tabular}{|c|c|c|c|c|c|c|c|c|}
\hline $\begin{array}{c}\alpha_{0} \\
\text { (intercept) }\end{array}$ & $\begin{array}{c}\alpha_{1} \\
\text { (trend) }\end{array}$ & $\begin{array}{l}\beta_{1} \\
\text { (LNYsa) }\end{array}$ & $\begin{array}{c}\delta_{1} \\
\left(\mathrm{FRI}_{1}\right)\end{array}$ & $\begin{array}{r}\phi_{1} \\
(\mathrm{R})\end{array}$ & $\begin{array}{c}\mu_{1} \\
\text { (DEV) }\end{array}$ & $\begin{array}{c}\gamma_{1} \\
\text { (DU98) }\end{array}$ & $\begin{array}{l}\text { R-Bar } \\
\text { Sq. }\end{array}$ & Diagnostic tests \\
\hline $\begin{array}{l}-14.09 \\
(3.25)\end{array}$ & $\begin{array}{l}-.0089 \\
(.002)\end{array}$ & $\begin{array}{c}.48 \\
(0.26)\end{array}$ & $\begin{array}{l}-.0011 \\
(.0003)\end{array}$ & $\begin{array}{l}-.0019 \\
(.0006)\end{array}$ & $\begin{array}{l}-.002 \\
(.0017)\end{array}$ & $\begin{array}{l}-.123 \\
(.049)\end{array}$ & .69 & $\begin{array}{l}\text { Serial Correlation: } \\
\chi^{2}(12)=15.6[.212]\end{array}$ \\
\hline $\begin{array}{l}\text { P-value } \\
{[.000]}\end{array}$ & $\begin{array}{l}\text { P-value } \\
{[.000]}\end{array}$ & $\begin{array}{r}\text {-value } \\
{[.065]}\end{array}$ & $\begin{array}{c}\text { P-value } \\
{[.003]}\end{array}$ & $\begin{array}{l}\overline{\text { P-value }} \\
{[0.002]}\end{array}$ & $\begin{array}{l}\text { P-value } \\
{[.183]}\end{array}$ & $\begin{array}{l}\text { P-value } \\
{[.015]}\end{array}$ & & $\begin{array}{l}\text { Functional Form: } \\
\chi^{2}(1)=2.36 \text { [.124] } \\
\text { Normality: } \\
\chi^{2}(1)=2.12 \text { [.347] } \\
\text { Heteroscedasticity: } \\
\chi^{2}(1)=.014[.706]\end{array}$ \\
\hline
\end{tabular}

Table 5: Summary of the results of estimating model (2) ${ }^{37}$

The empirical performance of the model is satisfactory. It passes diagnostic tests. All the coefficients with the exception of the rate of devaluation appear to be statistically significant. All but the interest rate variable have the expected signs. Theoretically, a real deposit interest rate should be positively correlated with financial deepening. Imposition of financial restraints should affect only the significance of this variable (reducing it), but not the direction of the relationship. However, the results above

\footnotetext{
${ }^{36}$ In fact, hypothesizing the prevalence of rational expectations in the formation of the rate of devaluation of the national currency, we pre-estimated the model by using the Generalised Instrumental Variable Method to account for a problem of measurement errors. Twice lagged values of the devaluation rate were used as instrumental variables. The results were unsatisfactory, with Sargan's $\chi^{2}$ statistic indicating model misspecification.

${ }^{37}$ Author's calculations on the data provided by the National Bank of the Republic of Belarus (National Bank of Belarus 2000a (January), 2000b (January), 2001, 2002, 2003). Standard errors are in round parentheses. To save space p-values are used here to denote statistical significance of the coefficients.
} 
show that the real deposit interest rate in Belarus was negatively correlated with financial depth. This may suggest that its repression was particularly severe. Indeed, even when the deposit interest rate was rising in real terms it still remained negative in most of the analysed period and in this way could not gain households' credibility to make them switching from investing in tangible assets and in purchase of foreign currency (cash) to depositing their earnings in banks. ${ }^{38}$ Furthermore, the FRI also exerts a direct negative impact on financial deepening that is independent of influence of FR through the real deposit rate of interest, and it is statistically significant at $1 \%$ level.

The results suggest that financial repression had an overall negative impact on financial deepening. Financial disintermediation could have had negative implications for economic growth in the long run, if the financial structure had mattered. In the case of Belarus, it seems likely that it did not, but given the estimation technique we can talk only about its contemporaneous effect. ${ }^{39}$

The effect of financial development on economic growth materialises through two major channels: capital accumulation (extensive growth), and technological change (intensive growth). As FR resulted in financial disintermediation and demonetisation, growth can hardly be attributed to capital accumulation. Perhaps paradoxically, the policy of macroeconomic expansion triggered liquidity contraction and consequently an increase in arrears and barter transactions.

There are two reasons why financial development did not raise growth through technological change. First, the state subsidies and banks' loans were mainly designed to support poorly performing state-owned enterprises in agriculture and industry to keep them afloat. Industrial policy was lacking 'strategic coherence and selectivity' and was unable to promote investment in specific sectors with strong growth potential and to 'spur structural change towards rapid modernisation of the

\footnotetext{
${ }^{38}$ Given high correlation between the rate of devaluation, real interest rate and FR index, a negative sign of the coefficient for the real interest rate can be attributed to multicollinearity in the model. To check this we performed some sensitivity analysis to see whether the estimates are different when 1) the rate of devaluation is removed from the equation, and 2) when deposit rate ceiling is removed when constructing the index of financial repression. The estimates appeared to be not much different from the ones obtained by estimating equation (2). So, both the sign and magnitude of the coefficient for the real interest rate were upheld. This suggests that the negative coefficient for the real interest rate is more likely to reflect a poor instrument.

${ }^{39}$ A performed Granger-causality test suggests a one-way relationship between income series and the first differences of LFD with the former Granger causing the latter (Fst.=1.83, p-value [0.066]). The $\mathrm{H} 0$ of the first differences of LFD Granger causing LNYsa cannot be rejected at any level of statistical significance (Fst. $=0.39$, p-value [0.96].
} 
economy' (Haiduk et al. 2004). As mentioned above, the pattern of credit and subsidies allocation and a policy of low interest rates resulted in problems of adverse selection and moral hazard that were the opposite extreme to what was pronounced by the policy of high interest rates. The investment did not go to support the newly created private enterprises that were mainly serviced by non-system forming banks. In the risky and information-limited environment where the law often had a retroactive force and inactive bankruptcy procedures existed, the majority of the latter were reluctant to lend to the real sector, preferring to operate in the interbank loan or foreign exchange markets. Furthermore, the economic mechanism envisaged not only direct but also implicit subsides to the state-owned enterprises in a form of tax exemption for some state-owned firms. This was at the expense of increasing the tax burden on the private sector, and granting access to cheap natural resources, which together led to a crowding out of the private entrepreneur from the market.

Second, due to the highly inflationary environment, mainly short-term loans were granted to finance enterprises’ working capital. The rate of capital depreciation fell from 6-8 per cent prior to 1991, to 1.5-2.4 per cent in 2002, suggesting that it would take 42-66 years instead of 12-16 years for full renewal of the fixed capital stock (Daneiko 2003, p.125). Overall capital depreciation reached 60 per cent in 2002 (ibid, p.125). Taken together this suggests that the average productivity of capital was expected to fall ${ }^{40}$, due to the replacement of high-yielding investment that can be generated in the private sector or in the branches of the economy with high technological potential with low-return investment, directed mainly to loss-making agricultural and industrial sectors, the inefficient house construction sector, and to stimulate household consumption through wage increases.

Therefore, neither lowering the cost of capital nor directed credits and preferential loans to SOEs - the two core FR policies in Belarus in the late 1990s could facilitate efficient capital allocation and consequently sustainable growth in the long run. The slowdown in growth in 1999-2002, growing inventories ${ }^{41}$, an increase in loss-making enterprises ${ }^{42}$ and significant deterioration of Belarus' competitive

\footnotetext{
${ }^{40}$ Unfortunately, there is no evidence supporting this conclusion due to the unavailability of the data on capital stock.

${ }^{41}$ As of 2002 inventories reached 65.3 per cent of current monthly output (Haiduk et al. 2004).

${ }^{42}$ The number of loss-making enterprises reached 35 per cent of all enterprises in 2002, as against 7.3 per cent in 1994. Overall profits tended to decrease - amounting to only 11.8 per cent of GDP in 2002 versus 52.9 per cent in 1994;
} 
position $^{43}$ all provide evidence of the inefficiency of the economic strategy. Belarus has neither attempted to create a competitive environment allowing for new entrants to the market and opening itself up for foreign direct investment, nor has it used the opportunity of high growth to promote structural and institutional reforms.

\section{Conclusion}

The Belarusian experience of financial repression has had an overall negative effect on financial development, resulting in shallow finance and financial intermediaries playing a passive role in the development process. If finance had mattered in the long run, financial repression would have been expected to inhibit economic growth through decreasing the share of savings to be allocated to investment and reducing the average productivity of capital. Therefore the financial policy pursued in 1996-2000 can be viewed as a 'survival-oriented strategy' rather than a 'growth-oriented strategy' (Bakanova et al. 2003) that, in the first place, aimed to serve the government's own needs in ensuring its political survival.

Although since 2000 government policies have been gradually adjusted towards reducing economic distortions, in particular in the financial sector, and GDP growth surged again from 4.5 per cent in 2002 to 11 per cent in 2004, the sustainability of the new growth pattern, and therefore social stability remains questionable. This is due to the delay in economic restructuring and the vulnerability to any change in the external environment. Since 2001 improvements in the external environment largely explain these high rates of economic growth. ${ }^{44}$ If the government continues to avoid fundamental reforms when growth is high $^{45}$, it puts the country under the risk of a severe transition crisis that will inflict even greater economic and social costs than after the Soviet Union's collapse.

\footnotetext{
${ }^{43}$ Competitiveness is an important determinant of economic growth in a small open economy such as Belarus. The erosion of Belarus' competitive advantage can be explained by high wage growth attributed to nominal wage increases and real currency appreciation (Zaiko 2005 and World Bank 2005).

${ }^{44}$ In 2001-2004 Belarus benefited directly from the growth in oil prices - through the expansion of oil processing exports, and indirectly - through accelerated growth and demand in Russia - which still remains the Belarus’ main trade partner (World Bank 2005).

${ }^{45}$ A high rate of growth allows for more smooth reforms. However, it is also true that when growth is high, the pressure for change is less.
} 


\section{References:}

Agarwala, R., 1983. Price distortions and growth in developing countries. World Bank Staff Working Paper, 575. Washington D.C.: World Bank.

Bakanova, M., deSouza, L. V., Kolesnikov, I. and Abramov, I., 2003. Explaining growth in Belarus [online]. Available from: http://www.gdnet.org/pdf/draft_country_studies/Belarus_final.pdf [Accessed 22 March 2003].

Daneiko, P., Pelipas, I. and Rakova, E., 2003. Belarus': vybor puti. Ekovest [online], Available from: http://www.ipm.by/index.pl?topicid=f9637dc3\&briefid=d98b85388206fc93 [Accessed 2 October 2004].

De Melo, M. and Denizer, C., 1997. Monetary policy during transition: an overview. Policy Research Working Papers, 1706. Washington D.C.: World Bank.

Demetriades, P. O. and Luintel, K. B., 1997. The direct costs of fiancial repression: evidence from India. Review of Economics and Statistics, 79 (2), pp. 311-20.

Demetriades, P. O. and Luintel, K. B., 2001. Financial restraints in the South Korean miracle. Journal of Developement Economics, 64 (2), pp. 459-79.

Fry, M. J., 1995. Money, interest, and banking in economic development. 2nd edition. Baltimore: The Johns Hopkins University Press.

Fry, M. J., 1997. In favour of financial liberalisation. The Economic Journal, 107 (May), pp. 754-770.

Haiduk, K., Herr, H., Lintovskaya, T., Parchevskaya, S., Priewe, J. and Tsiku, R., 2004. The Belarusian economy at a crossroads. Moscow: Actrav.

Hendry, D. F., 1995. Dynamic Econometrics. Oxford: Oxford University Press.

Institute of Privatisation and Management, Belaruskaia macroekonomicheskaya statistika [online]. Available from: http://ipm.by/index.pl?topicid=inside [Accessed September 2003].

International Monetary Fund, 1995.Belarus - recent economic developments, IMF Staff Country Report. Washington D.C.: IMF, (95/99).

Korosteleva, J. A., 2004. Continuity over change: Belarus, financial repression and reintegration with Russia. In: N. Robinson, ed. Reforging the weakest link. Hants, Burlington: Ashgate, pp. 61-80.

Ministry of Statistics and Analysis, 2002. Statistical Yearbook of the Republic of Belarus. Minsk: Statizdat. 
Ministry of Statistics and Analysis, 2003. Statistical Yearbook of the Republic of Belarus. Minsk: Statizdat.

McKinnon, R., 1973. Money and capital in economic development. Washington D.C.: Brookings Institution.

National Bank of the Republic of Belarus, 2000a (January). Dinamika denezhno-kreditnykh pokazatelei za 1995-1999 gody. Minsk: NBB.

National Bank of the Republic of Belarus, 2000b (January). Dinamika denezhno-kreditnykh pokazatelei za 1995-1999 gody. Minsk: NBB.

National Bank of the Republic of Belarus, 2001. Bulleten' bankovskoi statistiki. Minsk: NBB.

National Bank of the Republic of Belarus, 2002. Bulleten' bankovskoi statistiki. Minsk: NBB.

National Bank of the Republic of Belarus, 2003. Bulleten' bankovskoi statistiki. Minsk: NBB.

Nuti, D. M., 1999. Belarusian alternative: transition or solely reform. Belarusian Economic Trends, (April-June), pp. 15-20.

Roubini, N. and Sala-i-Martin, X., 1992. Financial repression and economic growth. Journal of Development Economics, 39, pp. 5-30.

Rusakevich, I., 2002. Monetarnaya politika Respubliki Belarus' In Belaruskaya ekonomika: ot rynka k planu, [online]. Minsk: Institute of Privatisation and Management. Available from: http://ipm.by/pdf/Book/1-05.pdf [Accessed 3 May 2003].

Shaw, E. S., 1973. Financial deepening in economic development. New York: Oxford University Press.

Silitski, V., 2002b. Palitychnaya ekanomiya Belaruska-Rasiiskai integratsyi. In: V. Bulgakau, ed. Belaruska-Rasiiskaya integratsyya: analitychnyya artykuly. Minsk: Entsyklapedyks, pp. 222-269.

Stiglitz, J., 1994. The role of the state in financial markets. In: M. Bruno and B. Pleskovic, eds. The World Bank Annual Bank Conference on Development Economics, 1993. Washington D.C.: World Bank, pp. 19-52.

Stiglitz, J. and Weiss, A., 1981. Credit rationing in markets with imperfect information. American Economic Review, 71 (3), pp. 393-410.

TACIS, 1999. Belarusian Economic Trends, January-March.

World Bank, 2005.Belarus: window of opportunity to enhance competitiveness and sustain economic growth, 10 June 2005. Washington D.C.: World Bank, (32346-BY). 
Zaiko, L., 2005. Konvergentnaya divergentsiya: paranormal'naya integratsiya [online]. Minsk:Nashe Mneniye. Available from:

http://nmnby.org/pub/190905/divergence.html [Accessed 24 September 2005]. 